\title{
THIAMINE DIPHOSPHATE SYNTHESIS AND REDOX STATE INDICATOR IN THE RAT BRAIN DURING B HYPOVITAMINOSIS
}

\author{
Yu. M. PARKHOMENKO, A. S. PAVLOVA, O. A. MEJENSKAYA, \\ S. P. STEPANENKO, L. I. CHEKHIVSKA
}

Palladin Istitute of Biochemistry, National Academy of Sciences of Ukraine, Kyiv; e-mail: yupark@biochem.kiev.ua

The main aim of this study was to reveal the relationship between thiamine metabolism and the redox balance of cellular metabolism in chronic alimentary thiamine deficiency. On the experimental model of chronic alimentary thiamine deficiency (hypovitaminosis) the dynamics of changes in the indicators of thiamine diphosphate (ThDP) synthesis and the redox state in rat brain tissue were studied. In the whole brain homogenate of the rat, the levels of ThDP and thiamine pyrophosphokinase (TPK) activity as well as the levels of free $\mathrm{SH}$-groups and reactive oxygen species (ROS) were measured. The results obtained showed, even with a very limited supply of thiamine into the body (model of alimentary hypovitaminosis), there was no increase in the level of ROS (one of the signs of oxidative stress) in the brain tissue, while the level of free SH-groups significantly decreased. Under these conditions the content of ThDP (the coenzyme form of thiamine) in brain tissue changes insignificantly that suggests that there are non-coenzymatic mechanisms of vitamin $B_{1}$ involvement in maintaining cellular redox homeostasis. The analysis of changes in the ThDP content and the TPK activity in the cerebral cortex, cerebellum and hippocampus of the rats' brain in the dynamics of hypovitaminosis development and TPK immunoreactivity at the end of the experiment showed that the ThDP synthesis in cells of various brain regions under the indicated conditions does not depend on the redox state, but is regulated by the level of ThDP.

Key words: thiamine, $B_{1}$ hypovitaminosis, thiamine diphosphate, thiamine kinase, thiamine in the brain regions, thiamine and oxidative stress.

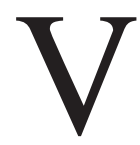
itamin $\mathrm{B}_{1}$ (thiamine) is one of the essential factors of human and animal nutrition, which constantly needs to be ingested into with food. The literature data indicates that the chronic vitamin $\mathrm{B}_{1}$ deficiency in the body leads to degenerative changes in the brain. Similar changes are observed in classic common neurodegenerative pathologies, such as Wernicke-Korsakoff syndrome (consequences of alcoholism), Alzheimer's disease, Parkinson's disease, etc. [1-4].

On the other hand, a lot of data indicate that almost all human neurodegenerative diseases are accompanied by thiamine deficiency (TD). That is why more and more researchers are using TD model as the experimental model of neurodegeneration [4-6]. However, the molecular mechanisms, which are responsible for interaction between the TD and the degenerative processes initiation, have not been clarified completely up to date. Although, the understanding of these mechanisms is a necessary step on the way of preventing and treating the neurodegenerative pathologies.

Strict classical forms of vitamin $\mathrm{B}_{1}$ deficiency are now extremely rare [7]. But the hypovitaminosis state (a chronic lack of vitamin $\mathrm{B}_{1}$ intake) is quite common even in developed countries [7, 8]. And this state may be the cause of negative changes in nerve cells, which could initiate the degenerative processes. At the same time the thiamine metabolism in the brain is poorly understood in both the alimentary avitaminosis and, especially, chronic hypovitaminosis $\mathrm{B}_{1}$.

(C) 2017 Parkhomenko Yu. M. et al. This is an open-access article distributed under the terms of the Creative Commons Attribution License, which permits unrestricted use, distribution, and reproduction in any medium, provided the original author and source are credited. 
It is known, that rats fed with thiamine-deficient diet demonstrate the constancy of the thiamine diphosphate (ThDP) level in the brain, as long as ThDP is "pumped" from other organs, and brain ThDP level declines only after the depletion of thiamine pool in other organs [9, 10]. In experimental chronic alcoholism model ThDP level in brain tissue is also maintained at a fairly constant level for a long time, while the activity of enzyme which is involved in its synthesis - thiamine pyrophosphokinase (TPK, 2.7.6.2) may decrease [10].

The information regarding thiamine metabolism changes in $\mathrm{B}_{1}$ hypovitaminosis condition is practically absent. In particular, it is unknown what kind of changes in ThDP synthesis occurs and how the intracellular redox state (redox balance) in the brain may vary under these conditions. A maintenance of normal intracellular redox status plays an important role in such processes as enzymatic activity, DNA synthesis, gene expression, and others. Small changes in intracellular levels of reactive oxygen species (ROS) are involved in intracellular signaling [11]. Thiol-containing molecules, such as glutathione, also play an important role in maintaining redox homeostasis and redox regulation. A major role in redox regulation is played by the process of modification of sulfhydryl groups in proteins. The participants in this process are, on the one hand, ROS, and on the other, thiol-containing molecules. Glutathione is a tripeptide (L- $\gamma$-glutamyl-L-cysteinyl glycine), a special property of which is the presence of a free sulfhydryl group. This compound is widely distributed in cells of different types and accounts $90-95 \%$ of the pool of low molecular weight thiols [12]. Due to the high level of glutathione (up to $10 \mathrm{mM}$ ) and the fact that the concentration of its reduced form is $1-2$ orders of magnitude higher than the concentration of the oxidized form, glutathione is the main redox buffer in cells [13]. Taking into account the abovementioned the level of reduced glutathione in tissues can be estimated from the index of the free SH-groups content.

The purpose of this study was to investigate the relationship between ThDP content, the activity and immunoreactivity of TPK and the violation of the redox state in brain tissue of rats in the process of $\mathrm{B}_{1}$ hypovitaminosis development. The level of ROS and the content of free reduced SH groups were used as indicators of the redox state of brain tissue.

\section{Materials and Methods}

Ethics statement. All animal procedures were conducted in accordance with the requirements of European Convention for the protection of Vertebrate Animals Used for Experimental and Other Scientific Purposes (Strasbourg, 1986) and the "Rules of work with the experimental animal" approved by the Commission for the Care, Maintenance and Use of Experimental Animals of the Palladin Institute of Biochemistry, NAS of Ukraine.

Animal experiment. Wistar rats, males, with initial weights of 75-85 g were used in the experiments. Two alimentary TD models were used in the experiments: alimentary hypovitaminosis (Hv-T) and alimentary avitaminosis (Av-T). Gubler's prescription $[14,15]$ was used as the basis for the TD diet. For Hv-T model to the TD diet thiamine was added at a dose of $200 \mu \mathrm{g}$ per $1 \mathrm{~kg}$ of feed (Hv-T). This dose corresponded to a $15-20 \%$ of animals' daily requirement for thiamine (taking into account the rats food intake - about 15-20 g per day) [16]. Pair-fed control rats were administered each orally $200 \mu \mathrm{g}$ of thiamine (dissolved in physiological saline) daily in addition to the TD diet. Four control and 4-5 experimental rats were selected at the beginning of the experiment and after 3, 4 and 5 weeks of keeping animals on the Hv-T diet to analyze the biochemical parameters indicated below. In total, 16 and 18 rats were used in the control and Hv-T groups, respectively. Animals in groups Av-T and Hv-T were housed one per cage.

The Av-T model rats $(n=12)$ were kept on the TD diet without the addition of thiamine, the control rats $(n=6)$ in this model were pair-fed with the same diet and also received a thiamine daily, in the same dose as in the Hv-T case. Av-T model development lasted 3.5 weeks. Thiamine, at a dose of $200 \mu \mathrm{g}$ per animal (this corresponds to about $2 \mathrm{mg}$ of thiamine per $1 \mathrm{~kg}$ of body weight [15], was injected to a half of the Av-T group of rats $(n=6)$ a day before the end of the experiment.

At the end of the experiment, the rats were decapitated and the liver, brains and its parts (cortex, cerebellum and hippocampus) were taken for analysis.

TPK activity and ThDP determination. The TPK activity was determined by the described method [17]. The principle of the method is to determine the ThDP amount formed after thiamine incu- 
bation with the TPK preparation - in our case with the tissue homogenates. The ThDP content was determined with the developed express-method using the apoenzyme of yeast apopyruvate decarboxylase (apoPDK) [17]. Aliquots of brain homogenates and samples (after homogenates incubation with thiamine, in the TPK activity determine case) were incubated in phosphate buffer $(\mathrm{pH}$ 6.8) with apoenzyme for $30 \mathrm{~min}$. The enzymatic determination of ThDP is based on its recombination as a coenzyme with apoPDK, and the alcohol dehydrogenase reaction with a pyruvate excess. The reaction was registered by NAD $\cdot \mathrm{H}_{2}$ oxidation. ApoPDK for the ThDP determination was obtained from brewer's yeast (Saccharomyces carlsbergensis) in the sulfate paste form [17], which was stored at $-20^{\circ} \mathrm{C}$. The apoenzyme was obtained from the paste just before the experiment. The amount of formed ThDP was calculated from the calibration curve, which was constructed using a standard ThDP reagent.

Western-blott analysis. The proteins were separated by their molecular weight using gel-electrophoresis in a polyacrylamide gel (PAGE) under denaturing conditions with the Laemmli method [18], in a vertical electrophoresis chamber (SCIE-PLUS, England). Samples for electrophoresis were diluted with a 4-fold sample buffer (125 mM Tris- $\mathrm{HCl}(\mathrm{pH} 6.8)$, $20 \%$ glycerol, 10\% SDS, $0.2 \mathrm{M}$ dithiothreitol, $0.1 \%$ bromophenol blue) and were heated for $5 \mathrm{~min}$ at $95^{\circ} \mathrm{C}$. Samples were applied at a rate of $100 \mu \mathrm{g}$ of protein per track. The concentration of the separating PAGE was $10 \%$. Nitrocellulose membrane was used for electrotransfer of proteins. Electrotransfer was performed for $2 \mathrm{~h}$ at a voltage of $100 \mathrm{~V}$. Sites of non-specific sorption on the membrane were blocked for two hours in PBS, which contained 5\% dried milk (Sigma, USA) and 0.1\% Tween-20. Further, the membrane was washed with PBST, incubated with primary antibodies (anti-TPK1 "Abcam", monoclonal) for $16 \mathrm{~h}$ at $4{ }^{\circ} \mathrm{C}$.

Nonspecifically bound antibodies were removed by washing in PBST (5 times for $3 \mathrm{~min}$ ), and then membrane was incubated with secondary antibodies conjugated with horseradish peroxidase (Sigma, USA, anti-rabbit, No. 9169). After washing, the immunoreactive zones were visualized using an ECL kit, the result was fixed on an X-ray film.

Measurement of total thiamine in the liver. To determine the total thiamine content in the liver, the tissue was homogenized. Thiamine and its phosphates were extracted by boiling in an acidic medium. For the phosphoric thiamine esters hydrolysis, the samples have been incubated for $18 \mathrm{~h}$ with acid phosphatase $\left(\mathrm{pH}_{\text {opt }} 4.5\right)$, after which the precipitate was separated by centrifugation. The supernatant was applied to the ion exchange resin IRC-50. After washing, the thiamine was eluted from the column with $0.1 \mathrm{~N} \mathrm{HCl}$. The thiamine determination in the eluates was carried out using well-known thiochrome method [17].

Redox state indices and total protein determination. The intracellular level of reactive oxygen species (ROS) was determined using a specific molecular reagent - 2',7'-dichlorohydrofluorescin diacetate ( $\left.\mathrm{H}_{2} \mathrm{DCF}-\mathrm{DA}\right)$ (Sigma, USA) [19]. The fluorescence intensity was measured with spectrofluorimeter (Perkin-Elmer LS-50) at an excitation and emission wavelength of 497 and $525 \mathrm{~nm}$, respectively, the slit width was $2.5-5.0 \mathrm{~nm}$. The measurements were carried out at room temperature $\left(21-23^{\circ} \mathrm{C}\right)$. Determination of the free SH-groups concentration was carried out using the Ellman reagent according to the previously described method [15].

The total protein content was determined by the Lowry method and spectrophotometrically at $280 \mathrm{~nm}$ [20].

Statistical analysis. The experimental data are presented as mean \pm SEM. Tissue extracts from each animal were analyzed separately, with the assays of each extract carried out in two or three replicates. The data from independent series of experiments were pooled. The total number of animals contributing to the results presented ( $n$ ) is indicated in the figure legends. Intergroup differences were estimated using the Student's $t$-test and were considered significant at $P<0.05$. For calculations and graphical presentation of the results obtained, we used software tool MS Office Excel 2007.

\section{Results and Discussion}

In order to get closer to the real life situation, in which the body often does not receive the required daily amount of thiamine, we [15] developed in previous studies the model of $\mathrm{B}_{1}$ hypovitaminosis (Hv-T model), in which the animals were receiving a diet only with $20 \%$ of the required thiamine. Experiments with the Hv-T model development continued over five weeks, with the Av-T - over three and a half weeks. According to the results obtained previously, rats in the Hv-T group up to 3 weeks of the diet feeding were still gaining weight, although they lagged behind the average weight of the control group. Since the fourth week of the experiment, in 
the Hv-T group the animals' weight was significantly reduced.

After the indicated periods of keeping animals on each diet, we analyzed the biochemical parameters, including the level of ROS and free SH-groups. Thiamine deficiency is usually associated with the development of oxidative stress [21]. However, under these conditions, we did not observe the ROS level increase in the Hv-T group - this index was $78.0 \pm 7.6 \%$ of the same value in the control group; the level of SH groups was $59.3 \pm 7.1 \%$, respectively. The TPK activity in the brain at the end of the experiment was $35 \%$ higher than in the control [15].

One of this study's tasks was to track the dynamics of changes in the studied parameters, starting from the third week of keeping animals on the Hv-T diet. The aim was to determine the correlation between the indices of the metabolic processes oxidation-reduction state and thiamine metabolism parameters in the rat brain. For comparison, a similar study was conducted for animals kept on the Av-T diet.

Thiamine metabolism parameters. As was mentioned earlier, it had been shown experimentally, that with insufficient intake of thiamine into the body, the brain maintained a constant level of thiamine to the last extent by pumping it from other organs, primarily from the liver, kidney and blood [9-10]. In our study the thiamine content in the animals' liver was considered as a relative indicator of thiamine depletion in the body.

A

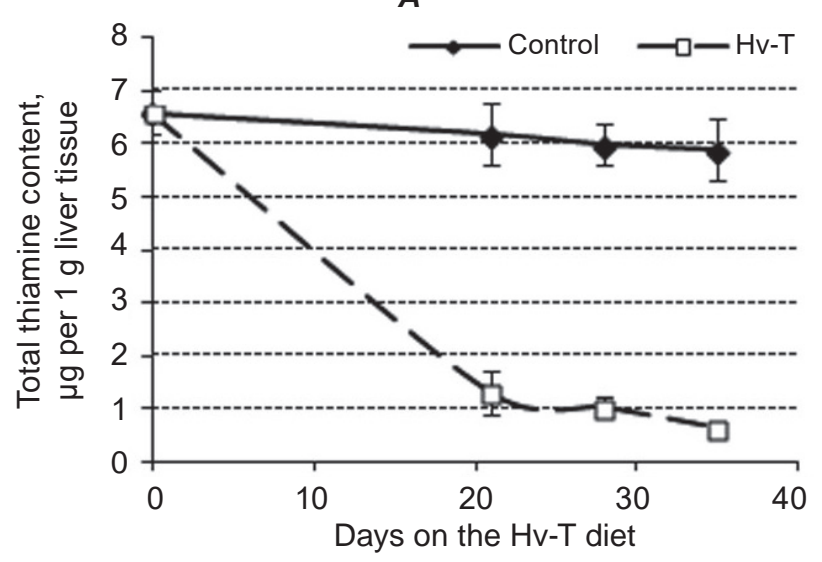

The data on the total thiamine content in the rats' liver in two series of experiments: $\mathrm{B}_{1}$-hypovitaminosis and $\mathrm{B}_{1}$-avitaminosis presented in Fig. 1, $A$ and $B$.

It should be noted that during the Hv-T development, after 3 weeks the thiamine content in the liver was $21.0 \pm 6.5 \%$ of its content in the control group. And at the end of the experiment this index was halved again. In the Av-T group vitamin depletion in the liver occured earlier - in 3.5 weeks this index was $10.8 \pm 1.7 \%$ of the control group and after a single administration of thiamine, this value did not increase significantly. Under the same conditions, we tested the ThDP content in the brain tissue homogenate using a sensitive enzymatic express method. The ThDP content in brain tissue of Hv-T rats after 3 weeks of maintenance on a thiamine-deficient diet decreased slightly, and even by the end of the experiment it differed little from the control one (Fig. 2).

The ThDP content in the brain tissue of the control animals and Hv-T animals did not differ significantly. But this was significantly lower relative to appropriate control in the Av-T group and a single injection of thiamine ( $200 \mu \mathrm{g}$ per day) did not lead to its normalization (Fig. 2, B).

Changes in ThDP metabolism parameters in different regions of the brain. The literature data show that in neurodegenerative pathologies (Wernicke-Korsakov syndrome, Alzheimer's and Parkinson's disease, etc.), as well as in TD, changes in different brain regions do not occur synchronously

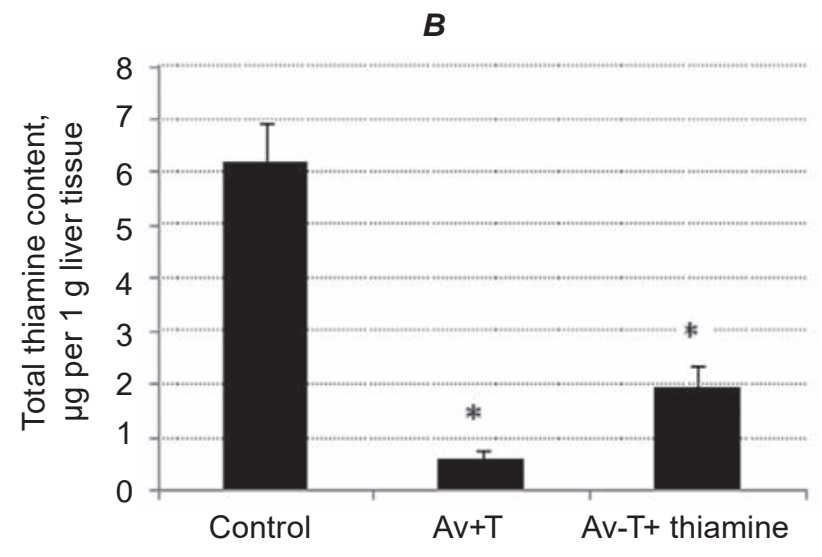

Fig. 1. The total thiamine content in the liver of experimental rats: $\boldsymbol{A}$-in the dynamics of $B_{1}$-hypovitaminosis development ( $H v-T$, for each point $n=4-5)$ and $\mathbf{B}$ - in the liver of $B_{1}$-avitaminous rats at the end of the experiment -3.5 weeks $(A v-T, n=6)$. The data are presented as the mean $\pm S E M$. Note: ${ }^{*} P<0.05$, statistically significant difference from control group. 

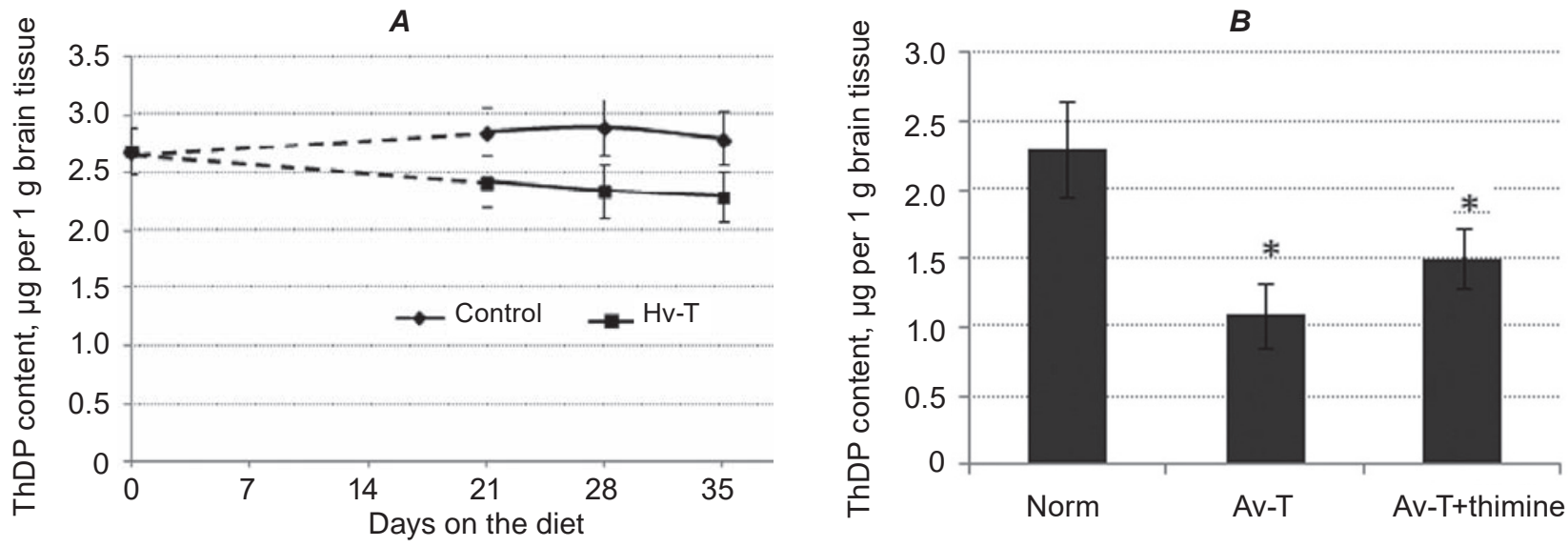

Fig. 2. ThDP content in the brain tissue of $B_{1}$-hypovitaminous rats $(H v-T)$ in the dynamics of $H v-T$ development (A, $n=4-5)$ and in the brain tissue of $B_{1}$-avitaminous rats $(A v-T, n=6)$ at the end of the experiment (B). The data are presented as the mean \pm SEM. ${ }^{*} P<0.05$, statistically significant difference from control group

[22-24]. Taking into account these observations, we considered it worthwhile to study changes in ThDP metabolism in different parts of the brain during the Hv-T development. In order to clarify this issue, we analyzed the ThDP content and the TPK activity in three brain areas: the cerebral cortex, the cerebellum and the hippocampus.

The data summarized in Fig. 3, indicate that the ThDP level in different brain areas fluctuates in a fairly wide range, but there is a tendency to maintain its constant level during 5 weeks on the Hv-T diet.

Characteristic changes were observed in the TPK activity in the three brain regions as Hv-T develops (Fig. 4, $A$ and $B$ ). Analysis of the data shown in Fig. 3 and Fig. 4 suggests that there is an inverse correlation between TPK activity and ThDP content (with some lag in TPK activity).

As can be seen from the data shown in Fig. 3 and 4, an increase in the TPK activity (per $1 \mathrm{mg}$ of protein) in the brain regions was observed only after the preliminary decrease in ThDP concentration to a certain level, and this process was probably accompanied by an increase in the ThDP production. Fig. 3, $A$ and $B$ show data on the TPK activity per $1 \mathrm{mg}$ of protein $(A)$ and $1 \mathrm{~g}$ of tissue $(B)$ for each part of the brain, so it can be seen that the ability of certain brain regions to synthesize ThDP in the dynamics of Hv-T development is not the same.

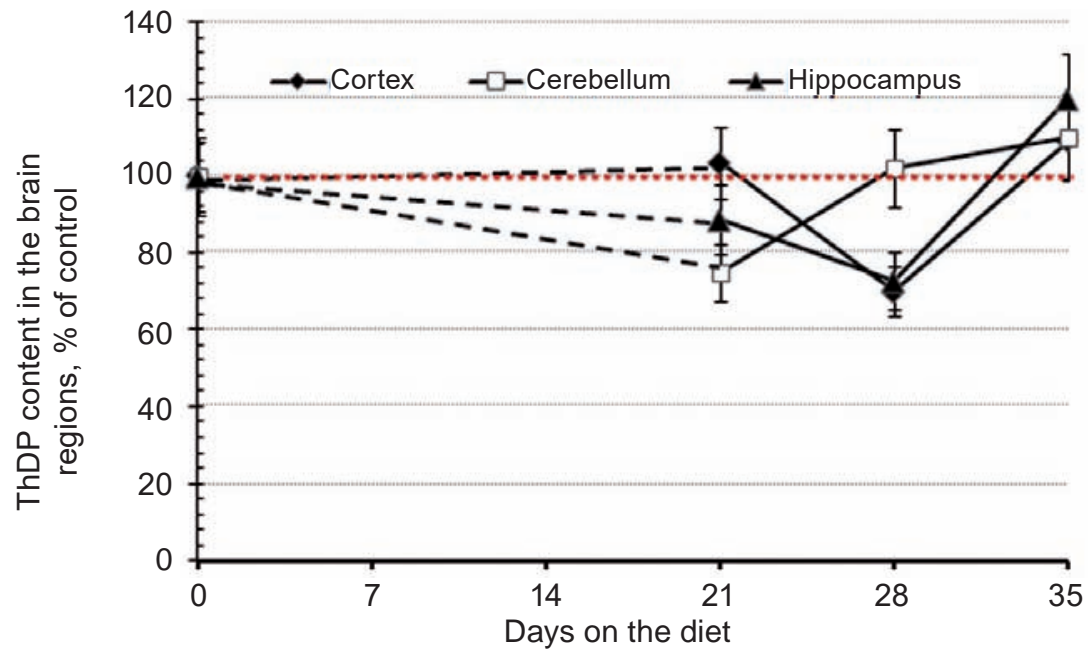

Fig. 3. ThDP content in the brain regions of $B_{1}$-hypovitaminous rats $(H v-T)$, in $\%$ of the same index for pairedfed control. The data are presented as the mean \pm SEM, for each point $n=4-5$ 

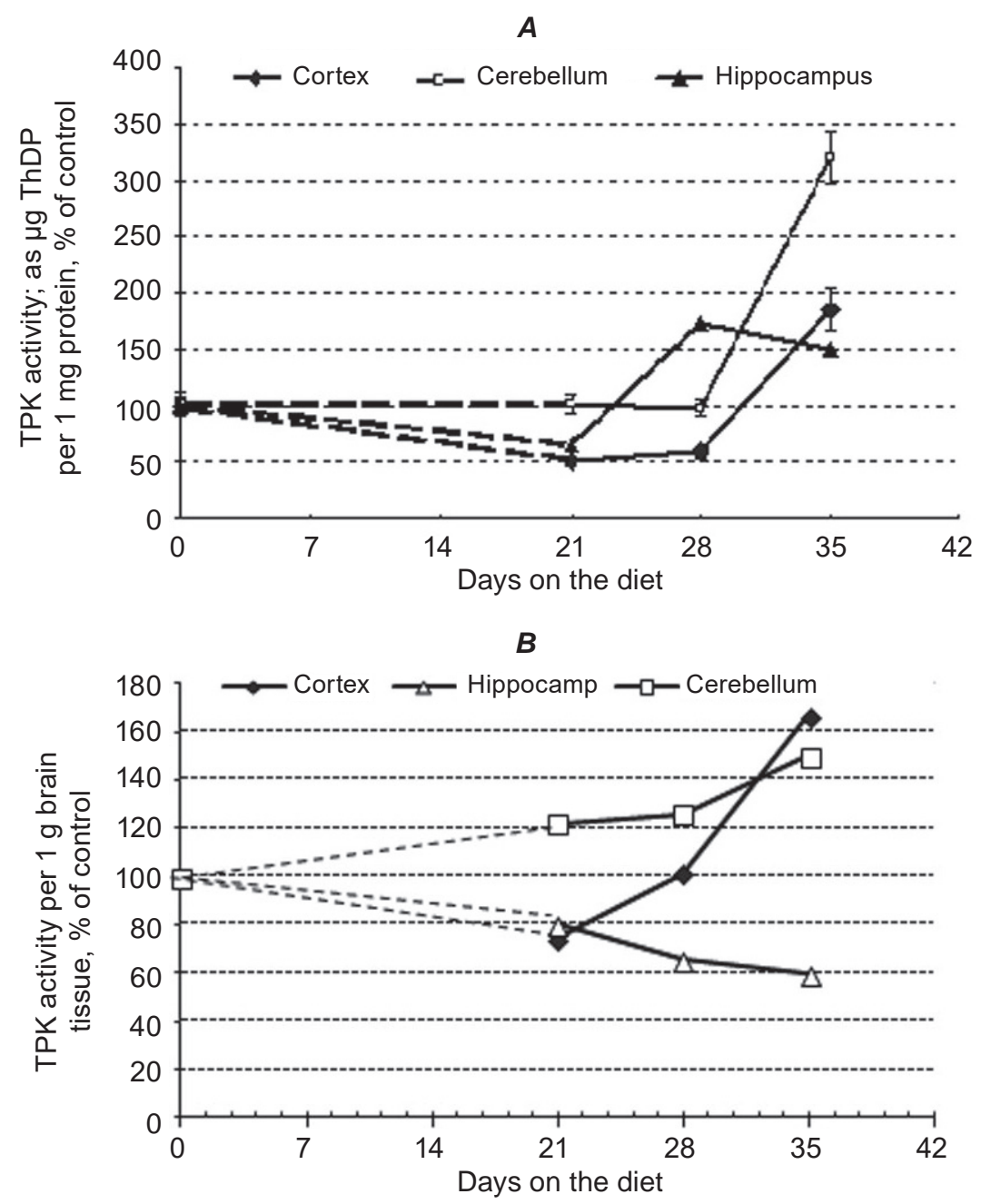

Fig. 4. TPK activity in the brain regions of $B_{1}$-hypovitaminous rats $(H v-T)$, per $1 \mathrm{mg}$ of protein (A) and $1 \mathrm{~g}$ of tissue (B), in \% of paired control. The data are presented as the mean \pm SEM, for each point $n=4-5$

Western blot analysis. To determine whether an increase in TPK activity occurs due to an increase in the amount of enzyme or TPK activity the regulation is carried out without changing in the protein amount, the enzyme immunoreactivity was tested at the end of the Hv-T experiment with Western blot analysis using anti-TPK antibodies.

The data shown in Fig. 5, confirm preliminary results about the TPK immunoreactivity increase in the brain regions at the late stages of Hv-T, which also may indicate an increase in the TPK protein level. Based on these data, it can be assumed that ThDP, as a reaction product, participates in the regulation of TPK expression in nerve cells.

Another picture of the change of TPK immunoreactivity in the brain regions was observed in the Av-T group. In this experiment, at the end, the Av-T rats were divided into two subgroups, one of which was administered per os thiamine at a dose of $200 \mu \mathrm{g}$ one day before decapitation. The purpose of administration was to test the thiamine metabolism system ability to respond to the vitamin intake under these conditions. The results are shown in Fig. 6.

As can be seen from the data presented, in the Av-T group the TPK immunoreactivity is significantly reduced in all three regions after 3.5 weeks of dietary maintenance. Resumption of thiamine supply promoted the normalization of this parameter in the cerebellum and hippocampus, but no such effect was observed in the cortex.

Parameters of the metabolism redox state. Simultaneously with the thiamine metabolism parameters determination, in both series of experiments, the general parameters characterizing the redox state of metabolism in the tissue were determined in the brain homogenates. The free SH-groups content 


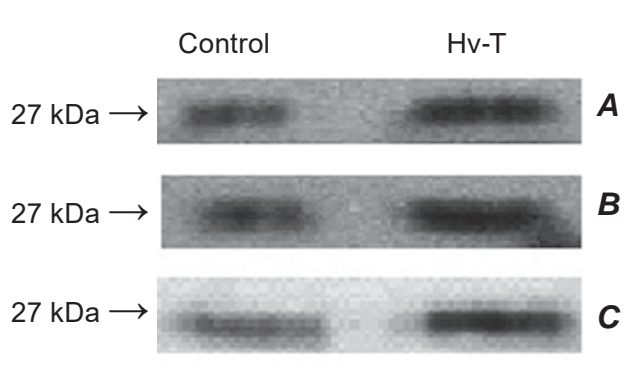

$A$

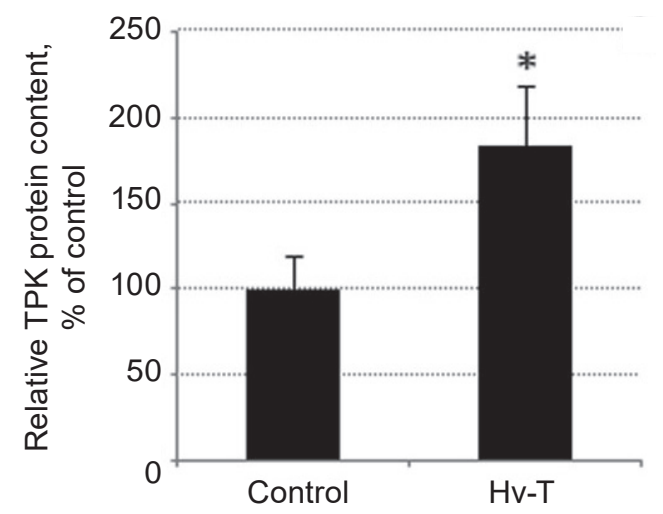

B

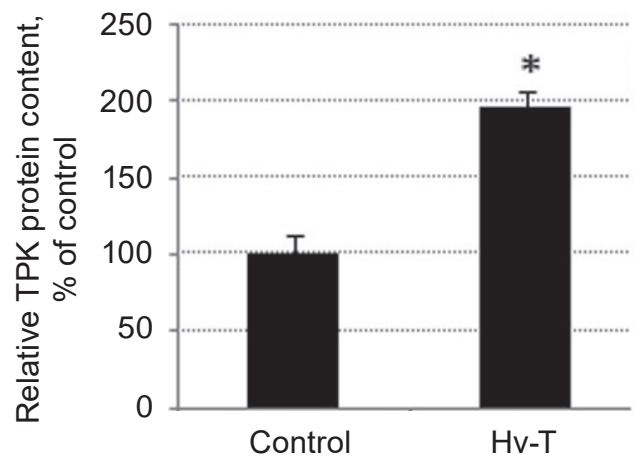

C

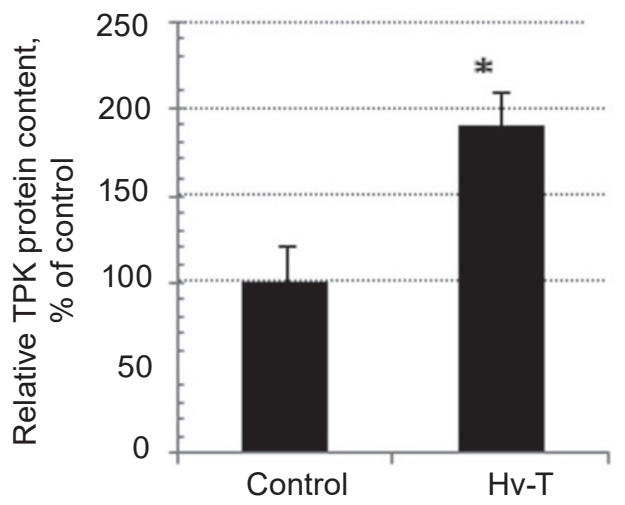

Fig. 5. Immunoreactivity of TPK in the three brain regions of control and hypovitaminous rats (Hv-T) after 5 weeks on the Hv-T diet: $\boldsymbol{A}$-cortex, $\boldsymbol{B}$-cerebellum, $\boldsymbol{C}$ - hippocampus (normalization - by the amount of protein, samples were applied at amount $100 \mu \mathrm{g}$ of protein per track for electrophoretic protein separation). The experiment was replicated three times, and the results were expressed as the mean \pm SEM in the histogram. $* P<0.05$, statistically significant difference from control group

(reflects the content of reduced glutathione) and the ROS level were determined. The data obtained are shown in Fig. 7 and 8.

As can be seen from the data given in Fig. 7, after 3 weeks on Hv-T and Av-T diets, in both groups of animals the free SH-groups level in the brain tissue decreases.

The indicator, which characterizes the level of reactions with the ROS formation, decreases in Hv-T group brains after three weeks of keeping them on a diet and continues to gradually decrease until the end of the experiment (Fig. 8). In the Av-T group, in three weeks, the ROS level, on the contrary, is significantly higher than the same value in the control (Fig. 8). The ROS level reduction during the whole experiment in the Hv-T group can be explained by the slowing down of the oxidation-reduction reactions in the brain cells. Furthermore it could be, that the amount of thiamine, which goes to the brain under these conditions, is sufficient to neutralize the free oxygen radicals excess. This is quite possible, given that thiamine derivatives are able to interact with such structures [25].

Analysis of the data on the evaluation of the redox state in rats' brain tissue in two TD forms shows that in the condition of a slow decrease in the thiamine body's supply level (hypovitaminosis), there are no obvious signs of oxidative stress in the brain (Fig. 8, A), as may be evidenced by an increase in the ROS level. At the same time, under these conditions, the glutathione level (which prevails in the pool of low molecular weight thiols) is significantly reduced and is reflected in our study as a "free $\mathrm{SH}$ groups" indicator (Fig. 8, A). In the brain tissue of Av-T group animals, the glutathione content is also decreased (Fig. 7, B), while the level of ROS is significantly increased (Fig. 8, B) .

Comparing the above data (estimation of some indicators of the redox state in the brain tissue, data on the ThDP content, TPK activity and TPK immu- 

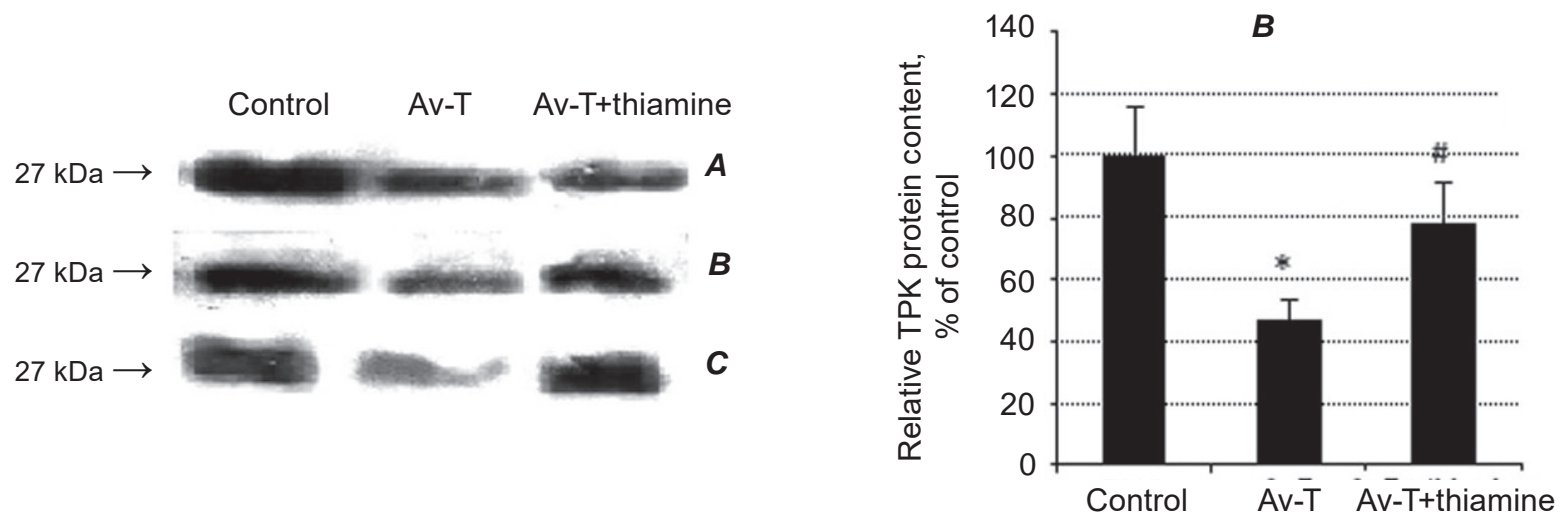

A
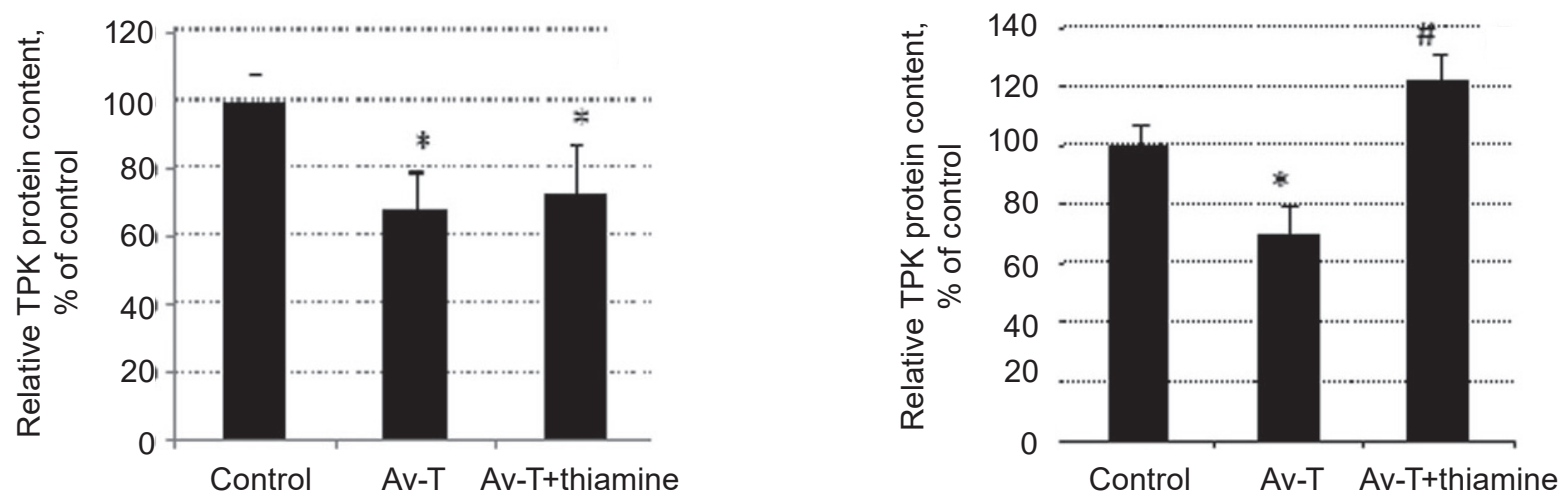

Fig. 6. Imunoreactivity of TPK (\% of control) in three brain regions of control, avitaminosis (Av-T) and Av-T + thiamine rats: $\boldsymbol{A}$ - cortex, $\boldsymbol{B}$ - cerebellum, $\boldsymbol{C}$ - hippocampus (normalization - by the amount of protein, samples were applied at amount $100 \mu \mathrm{g}$ of protein per track for electrophoretic protein separation). Rats were on Av-T diet for 3,5 weeks, thiamine was administered a day before decapitation. The experiment was replicated three times, and the results in \% of control were expressed as the mean \pm SEM in the histogram. $* P<0.05$, statistically significant difference from control group, $\# P<0.05$, as compared with the index in the Av-T group

A

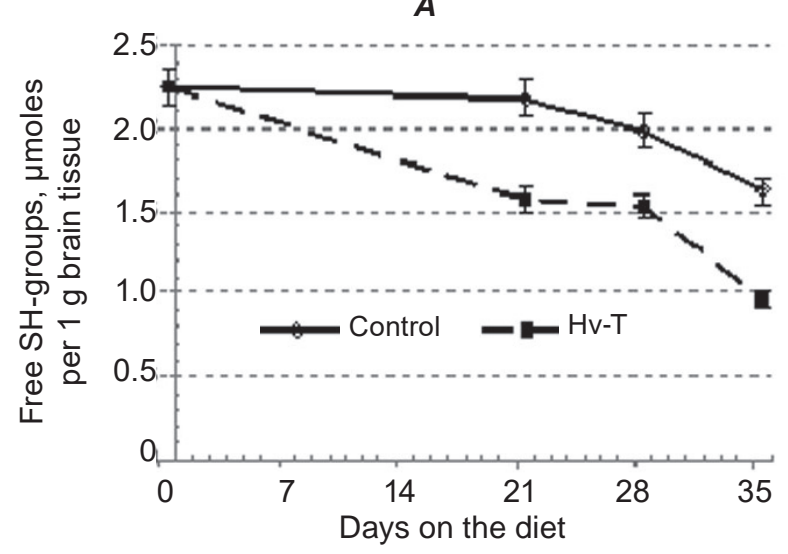

B

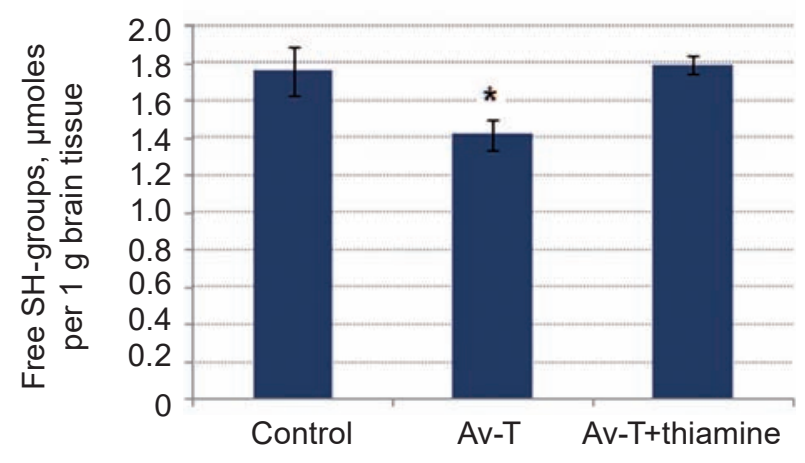

Fig. 7. Content of free SH-groups in the brain tissue of hypovitaminous rats $(H v-T)$ in dynamics (A, for each point $n=4-5)$ and rats on avitaminous diet $(A v-T)$ at the end of the experiment $(\boldsymbol{B}, n=6)$. The data are presented as the mean $\pm S E M, * P<0.05$, statistically significant difference from control group 


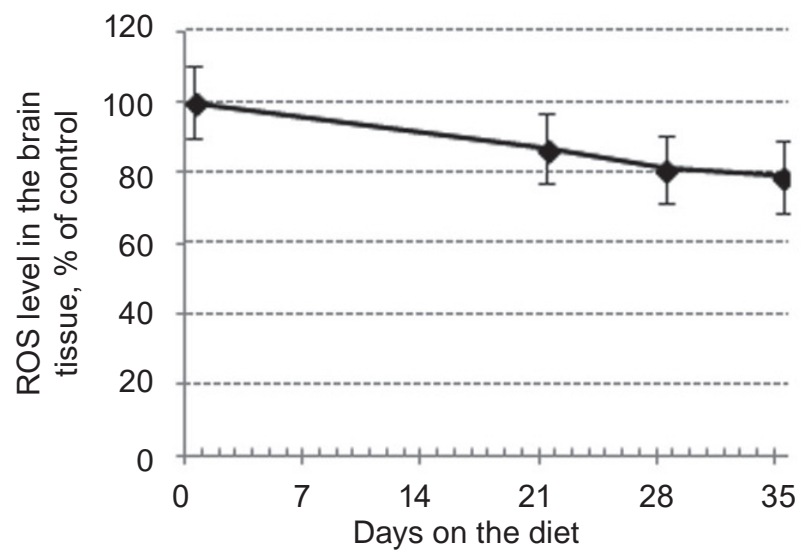

B

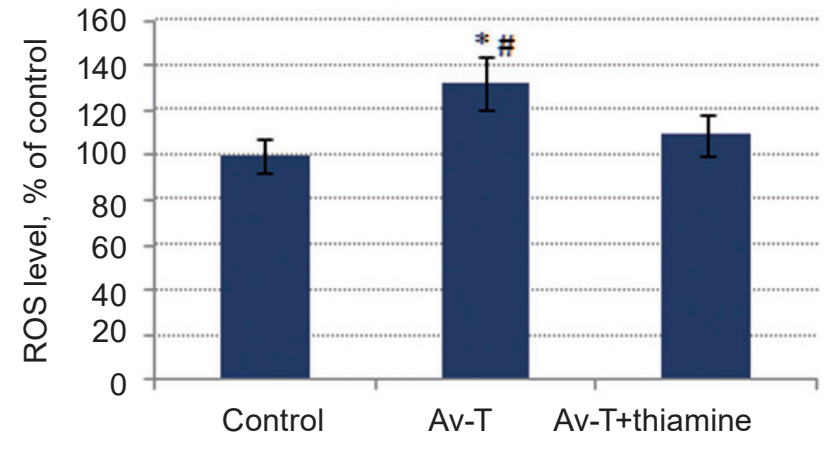

Fig. 8. ROS level in the brain tissue of hypovitaminous rats $(H v-T)$ in dynamics $(\mathbf{A}$, for each point $n=4-5)$ and avitaminous rats $(A v-T)$ at the end of the experiment $(\boldsymbol{B}, n=6), \%$ of the control. The data are presented as the mean $\pm S E M$, $* P<0.05$, statistically significant difference from control group, $\# P<0.05$, as compared with the index in the Av-T + thiamine group

noblotting in the brain regions in Hv-T (Fig. 2, $A$ and Fig. 6, A), we can conclude that under these conditions the TPK activity in different parts of the brain does not depend on the intracellular redox state, but is regulated by the ThDP level in an unknown way. A different picture was observed with Av-T. In this case, not only the reducing capacity of the cells decreases (the reduced glutathione content reduction, Fig. 7, B), but also the level of ROS increases (Fig. 8, $B$ ), which indicates the development of oxidative stress in brain tissue. It can be assumed that under these conditions, TPK activity and immunoreactivity decrease (Fig. 6, $B$ ) is partly a consequence of the protein modification due to changes the intracellular redox state [26, 27]. These changes are reversible and, as can be seen from the data presented, even with a single thiamine administration, redox state normalization was observed.

At the same time, single thiamine administration was not enough for ThDP level rapid normalization in the brain tissue of Av-T rats. The data obtained may indicate that the primary reason for the disturbance of redox balance in thiamine deficiency may be a decrease in the intracellular pool of thiamine and its biologically active derivatives, which in themselves are capable to neutralize free-radical compounds [25, 28]. However, this assumption requires further experimental proof. 


\section{СИНТЕЗ ТІАМІНДИФОСФАТУ І ПОКАЗНИКИ ОКИСНО- ВІДНОВНОГО СТАНУ ТКАНИНИ МОЗКУ ЩУ РІВ ЗА РОЗВИТКУ ГІПОВІТАМІНОЗУ B $_{1}$}

Ю. М. Пархоменко, О. С. Павлова, О. О. Меженська, С. П. Степаненко, Л. I. Чеховська

\author{
Інститут біохімії ім. О. В. Палладіна \\ НАН України, Київ; \\ e-mail: yupark@biochem.kiev.ua
}

Метою цього дослідження було виявити взаємозв'язок між обміном тіаміну і станом окислювально-відновного гомеостазу в клітинах мозку при хронічному аліментарному дефіциті тіаміну. На експериментальній моделі хронічної аліментарної недостатності тіаміну (гіповітаміноз) досліджено динаміку змін в показниках синтезу тіаміндифосфату (ТДФ) і загальних показниках редокс-балансу метаболічних процесів у тканині мозку щурів. У цілісному гомогенаті мозку щурів вимірювали рівень ТДФ і активність тіамінпірофосфокінази

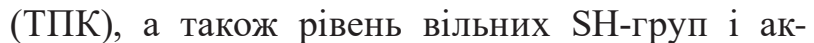
тивних форм кисню (АФК). Одержані результати показали, що навіть за дуже обмеженого надходження тіаміну в організм (модель аліментарного гіповітамінозу) не спостерігалося підвищення рівня АФК (одного з ознак окисного стресу) в тканині мозку, в той час як рівень вільних SН-груп істотно знижувався. У цих умовах вміст ТДФ (коензимної форми тіаміну) в тканині мозку змінювався незначно, що дало підстави припустити існування некоензимних механізмів участі вітаміну $\mathrm{B}_{1}$ у підтриманні клітинного редокс-гомеостазу. Аналіз змін у вмісті ТДФ і активності ТПК у корі, мозочку і гіпокампі мозку щурів у динаміці розвитку гіповітамінозу і імунореактивності ТПК в кінці експерименту показав, що синтез ТДФ в клітинах різних відділів мозку не залежить від окислювально-відновного стану метаболізму, а регулюється рівнем ТДФ.

К л ю ч о в і с ло в а: тіамін, тіаміндифосфат, гіповітаміноз $\mathrm{B}_{1}$, тіамінпірофосфокіназа, обмін тіаміну в відділах мозку, тіамін і оксидативний стрес.

\section{СИНТЕЗ ТИАМИНДИФОСФАТА И ПОКАЗАТЕЛИ ОКИСЛИТЕЛЬНО- ВОССТАНОВИТЕЛЬНОГО СОСТОЯНИЯ ТКАНИ МОЗГА КРЫС ПРИ ГИПОВИТАМИНОЗЕ В}

\author{
Ю. М. Пархоменко, А. С. Павлова, \\ О. А. Меженская, С. П. Степаненко, \\ Л. И. Чеховская
}
Институт биохимии им. А. В. Палладина НАН Украины, Киев: e-mail: yupark@biochem.kiev.ua

Целью данного исследования было выявить взаимосвязь между обменом тиамина и состоянием окислительно-восстановительного гомеостаза в клетках мозга при хроническом алиментарном дефиците тиамина. На экспериментальной модели хронической алиментарной недостаточности тиамина (гиповитаминоз) исследована динамика изменений в показателях синтеза тиаминдифосфата (ТДФ) и в общих показателях редокс-баланса ткани мозга крыс. В цельном гомогенате мозга крыс измеряли уровень ТДФ и активность тиаминпирофосфокиназы (ТПК), а также уровень свободных SH-групп и активных форм кислорода (АФК). Установлено, что даже при очень ограниченном поступлении тиамина в организм (модель алиментарного гиповитаминоза) в ткани мозга не наблюдалось повышение уровня АФК (одного из признаков окислительного стресса), в то время как уровень свободных SH-групп существенно снижался. В этих условиях содержание ТДФ (коэнзимной формы тиамина) в ткани мозга изменялось незначительно, что дало основания предположить существование некоэнзимных механизмов участия витамина $\mathrm{B}_{1}$ в поддержании клеточного редокс-гомеостаза. Анализ изменений в содержании ТДФ и активности ТРК в коре, мозжечке и гиппокампе мозга крыс в динамике развития гиповитаминоза и иммунореактивности ТРК в конце эксперимента показал, что синтез ТДФ в клетках различных отделов мозга не зависит от окислительно-восстановительного состояния метаболизма, а регулируется уровнем ТДФ.

К л ю ч в в е с ло в а: тиамин, тиаминдифосфат, гиповитаминоз $\mathrm{B}_{1}$, тиаминкиназа, обмен тиамина в отделах мозга, тиамин и оксидативный стресс. 


\section{References}

1. Butterworth RF, Kril JJ, Harper CG. Thiaminedependent enzyme changes in the brains of alcoholics: relationship to the WernickeKorsakoff syndrome. Alcohol Clin Exp Res. 1993; 17(5): 1084-1088.

2. Lu'o'ng Kv, Nguyen LT. Role of thiamine in Alzheimer's disease. Am J Alzheimers Dis Other Demen. 2011; 26(8): 588-598.

3. Lu'o'ng Kv, Nguyên LT. Thiamine and Parkinson's disease. J Neurol Sci. 2012; 316(1-2): 1-8.

4. Liu D, Ke Z, Luo J. Thiamine Deficiency and Neurodegeneration: the Interplay Among Oxidative Stress, Endoplasmic Reticulum Stress, and Autophagy. Mol Neurobiol. 2017; 54(7): 5440-5448.

5. Parkhomenko YuM, Pavlova AS, Mezhenskaya OA. Mechanisms responsible for the high sensitivity of neural cells to vitamin $\mathrm{B}_{1}$ deficiency. Neurophysiol. 2016; 48(6): 429-448.

6. Jhala SS, Hazell AS. Modeling neurodegenerative disease pathophysiology in thiamine deficiency: consequences of impaired oxidative metabolism. Neurochem Int. 2011; 58(3): 248260.

7. Gaüzère BA, Aubry P. The disease called "Barbiers" in the 19th century. Med Sante Trop. 2014; 24(3): 241-246.

8. Prinzo ZW. Thiamine deficiency. World Health Organization, 1999. $52 \mathrm{p}$.

9. Tumanov VN, Trebukhina RV. Interstitial thiamine redistribution during the development of vitamin $\mathrm{B}_{1}$ deficiency in mice. Vopr Pitan. 1987; (6): 49-52. (In Russian).

10. Parkhomenko YM, Kudryavtsev PA, Pylypchuk SY, Chekhivska LI, Stepanenko SP, Sergiichuk AA, Bunik VI. Chronic alcoholism in rats induces a compensatory response, preserving brain thiamine diphosphate, but the brain 2-oxo acid dehydrogenases are inactivated despite unchanged coenzyme levels. J Neurochem. 2011; 117(6): 1055-1065.

11. Oktyabrsky ON, Smirnova GV. Redox regulation of cellular functions. Biochemistry (Mosc). 2007; 72(2): 132-145.

12. Kulinsky VI, Kolesnichenko LS. The biological role of glutathione. Usp Sovrem Biol. 1990; 110(1): 20-23.

13. Robaczewska J, Kedziora-Kornatowska K, Kozakiewicz M, Zary-Sikorska E, Pawluk H, Pawliszak W, Kedziora J. Role of glutathione metabolism and glutathione-related antioxidant defense systems in hypertension. J Physiol Pharmacol. 2016; 67(3): 331-337.

14. Bai P, Bennion M, Gubler CJ. Biochemical factors involved in the anorexia of thiamin deficiency in rats. J Nutr. 1971; 101(6): 731-737.

15. Pavlova AS, Stepanenko SP, Chehovskaya LI, Tihomirov AA, Parkhomenko YuM. Dependence of vitamin $B_{1}$ metabolism and the state of astroglia in the rat brain on the supply with this vitamin. Neurophysiology. 2016; 48(5): 336-345.

16. Zapadnyuk IP, Zapadnyuk VI, Zakhariya EA. Laboratory animals. Breeding, content, use in the experiment, K: Vishcha shk., 1983. 383 p. (In Russian).

17. Ostrovsky YuM. Experimental vitaminology. M: Science and technology, 1979. 551 p. (in Russian).

18. Laemmli UK. Cleavage of structural proteins during the assembly of the head of bacteriophage T4. Nature. 1970; 227(5259): 680-685.

19. Zhang X, Cao J, Jiang L, Zhong L. Suppressive effects of hydroxytyrosol on oxidative stress and nuclear Factor-kappaB activation in THP-1 cells. Biol Pharm Bull. 2009; 32(4): 578-582.

20. Severin SYe, Solovieva GA. Practical work on biochemistry. Moscow: MSU, 1989. 509 p. (In Russian).

21. Gibson GE, Zhang H. Interactions of oxidative stress with thiamine homeostasis promote neurodegeneration. Neurochem Int. 2002; 40(6): 493-504.

22. Rindi G, Comincioli V, Reggiani C, Patrini C. Nervous tissue thiamine metabolism in vivo. II. Thiamine and its phosphoesters dynamics in different brain regions and sciatic nerve of the rat. Brain Res. 1984; 293(2): 329-342.

23. Ferreira-Vieira TH, de Freitas-Silva DM, Ribeiro AF, Pereira SR, Ribeiro ÂM. Perinatal thiamine restriction affects central GABA and glutamate concentrations and motor behavior of adult rat offspring. Neurosci Lett. 2016; 617: 182-187.

24. Vetreno RP, Hall JM, Savage LM. Alcoholrelated amnesia and dementia: animal models have revealed the contributions of different etiological factors on neuropathology, neurochemical dysfunction and cognitive impairment. Neurobiol Learn Mem. 2011; 96(4): 596-608. 
25. Parkhomenko YuM, Stepuro II, Donchenko GV, Stepuro VI. Oxidized derivatives of thiamine: formation, properties, biological role. $U k r$ Biokhim Zhurn. 2012; 84(6): 5-24. (In Russian).

26. Agrawal A, Rathor R, Suryakumar G. Oxidative protein modification alters proteostasis under acute hypobaric hypoxia in skeletal muscles: a comprehensive in vivo study. Cell Stress Chaperones. 2017; 22(3): 429-443.

27. Korolainen MA, Goldsteins G, Nyman TA, Alafuzoff I, Koistinaho J, Pirttilä T. Oxidative modification of proteins in the frontal cortex of Alzheimer's disease brain. Neurobiol Aging. 2006; 27(1): 42-53.
28. Vignisse J, Sambon M, Gorlova A, Pavlov D, Caron N, Malgrange B, Shevtsova E, Svistunov A, Anthony DC, Markova N, Bazhenova N, Coumans B, Lakaye B, Wins P, Strekalova T, Bettendorff L. Thiamine and benfotiamine prevent stress-induced suppression of hippocampal neurogenesis in mice exposed to predation without affecting brain thiamine diphosphate levels. Mol Cell Neurosci. 2017; 82: 126-136. 